\title{
Revised Trauma Score (RTS) as a Mortality Predictor on Abdominal Trauma
}

Ade Dian Anggraini ${ }^{1}$, Alsen Arlan ${ }^{1 *}$, Legiran $^{2}$

${ }^{1}$ Department of Surgery, Faculty of Medicine, Universitas Sriwijaya

${ }^{2}$ Department of Anatomy, Faculty of Medicine, Universitas Sriwijaya

*Correspondence author email: $\underline{\text { alsendst@yahoo.com }}$

\begin{abstract}
Introduction: Trauma is a major health problem throughout the world. Trauma is the most common cause of death and the most common cause of disability in adults and young adults. Abdominal trauma accounts for 7-10\% of all trauma sufferers and causes severe trauma. The purpose of this study was to determine the relationship between the Revised Trauma Score (RTS) to the mortality of abdominal trauma sufferers.
\end{abstract}

Methods: This study was an observational analytic study with a retrospective design to assess the relationship between Revised Trauma Score (RTS) and mortality in abdominal trauma patients treated in the Emergency Department of RSUP DR. Mohammad Hoesin Palembang. Data collected were analyzed using SPSS-23 devices using the chi-square method and Mann Whitney

Results: 144 abdominal trauma patients studied. The mean age was $28 \pm 11,340$ years, $97.4 \%$ were male, $64.0 \%$ of patients had abdominal trauma. The average RTS value was $7.429 \pm 1,001$. The mean value in the group of patients who died was $6.628 \pm 0.795$ and the mean value of the RTS in the group of patients who did not die was $7.459 \pm 0.795$. There was a significant relationship between RTS values and mortality in abdominal trauma patients $(\mathrm{p}=0.0 .03)$.

Conclusion: the results of this study indicate that RTS is a meaningful assessment system in predicting death in abdominal trauma patients

Keywords: revised trauma score, mortality predictor, abdominal trauma 


\section{Introduction}

Trauma is an injury or damage that occurs due to external factors ${ }^{1}$. Trauma is the cause of death for 16,000 people worldwide every day or around 5.8 million people each year and is estimated to cause 8.4 million deaths annually in 20202. Trauma is the main cause of disability in young people and is the main cause of death throughout world ${ }^{1}$. Incidence varies from country to country. Based on national statistics, England and Wales recorded mortality and hospitalization due to trauma reaching 1,095 / 100,000 population ${ }^{2}$. In the United States is a leading cause of death and disability. Every year 79,000 deaths are recorded in patients younger than 45 years. Whereas in Indonesia trauma is the number four cause of death while in the age group 15-25 years trauma is the main cause of death ${ }^{3}$.

Abdominal trauma is often a cause of death, which is $7-10 \%$ of trauma patients. Abdominal trauma is broadly divided into two, namely blunt trauma and penetrating trauma depending on the mechanism of trauma. The mechanism of trauma can be either direct trauma or trauma without any injuries penetrating the abdominal cavity. The most common cause of blunt abdominal trauma is a traffic accident followed by a fall from height and physical violence. The most common cause of penetrating abdominal trauma is stab wounds, gunshot wounds and any injuries that penetrate the peritonium cavity. ${ }^{4}$

Trauma management is one of the main challenges in health care at this time. An objective assessment of the degree of injury must be carried out so that a system that unifies the description and quantification of the injury is needed. The assessment of injuries as a process of quantifying the impact of trauma was begun in 1969 by the American Association for Automotive Safety, the Abbreviated Injury Scale (AIS) and continued to develop. The trauma assessment system tries to translate the severity of the injury into a number, used in the field before the patient reaches the hospital for referral decisions and makes decisions in the Emergency Department. Measurement of injury severity is an important prerequisite for effective trauma management. ${ }^{5}$

Trauma is a time-sensitive condition, especially management in the first hours after trauma, assessment, resuscitation and definitive management is very important. Faster management of trauma centers has been shown to reduce mortality. An easy trauma assessment system is applied 


\section{SSS SRIWIJAYA JOURNABOFSURGERУ}

can provide information to the medical team to assess the severity of the patient so that they can decide on trauma management in that patient. The trauma assessment system has two uses, namely at the field where the patient has not yet arrived at the hospital, to decide whether the patient needs to be referred to the trauma center or sufficient to the nearest hospital. The second function is when the patient is already in the Emergency Department (IGD), to assess whether this patient needs emergency surgery and to inform the patient's family about the patient's condition and the patient's plan of planning. ${ }^{6}$

Trauma assessment system is a screening tool or prognosis evaluation based on anatomic and physiological changes in trauma patients. ${ }^{7}$ An evaluation of this scoring system can estimate and analyze survival probability (SP) in trauma patients and be a comparison of the quality of care services. documentation of the degree of injury to trauma patients including clinical parameters, registration of epidemiological characteristics and quality of emergency services that will aim to improve the quality of care of trauma patients ${ }^{8}$. Several methods of trauma assessment systems have been proposed. Initially this trauma assessment system was applied to pre-hospital triage. This method was based on anatomical, physiological and combination criteria of both ${ }^{9}$. Injury Severity Score (ISS) and the New Injury Severity Score (NISS) were scoring based on anatomic changes in trauma patients while the Glasgow coma scale (GCS) and Revised Trauma Score (RTS) based on physiological changes in trauma patients. A severity characterization of trauma (ASCOT) and Trauma Related Injury Severity Score (TRISS) is a combination of anatomical and physiological changes in trauma patients. ${ }^{9}$

The application of the revised trauma score (RTS) began in 1989. RTS is a physiological

state assessment system with very high and accurate reliability in predicting death. ${ }^{10} \mathrm{RTS}$ has been widely applied in emergency department around the world. The use of RTS allows quick assessment at pre-hospital using three clinical variables, namely the Glasgow coma scale (GCS), systolic blood pressure and respiratory rate. RTS has been proven to predict mortality, injury severity, multiple trauma patient outcomes and length of stay in trauma patients. ${ }^{11}$ According to research conducted by Roy et al in Mumbai India in 2016 found that RTS is the best trauma assessment system in predicting death, does not require a fee and has the fewest valuation variables. In this study also concluded that there was no significant difference between RTS and TRISS in predicting death in trauma patients. While the TRISS examination takes longer and is 


\section{STS SRIWIJAYA JOURNAB OFEURGERY}

expensive. In a study conducted by Kim SC et al in South Korea in 2017 stated that the value of Area Under Curve (AUC) RTS is not too different from TRISS, where the AUC RTS value is 0.919 (95\% degree of confidence) and the AUC TRISS value is 0.952 (degree of confidence 95\%) .${ }^{13}$ Another study by Miller RT et al in the United States in 2017 also found that AUC RTS was higher than ISS. Where the AUC RTS is 0.959 (95\% confidence level) and the AUC on the ROC ISS is 0.780 (95\% confidence level).$^{14}$ This study was the first study that attempts to determine the role of the RTS screening system in predicting the mortality of patients with abdominal trauma, both blunt trauma abdomen or penetrating abdominal trauma.

\section{Methods}

This study was an observational analytic study with a retrospective design to assess the relationship between Revised Trauma Score (RTS) and mortality in abdominal trauma patients treated at the Emergency Department of general hospital DR. Mohammad Hoesin Palembang. This study was approved by the ethics committee of the Faculty of Medicine, Sriwijaya University (No.231 / kptfkunsri-rsmh / 2017). The sample of the study was abdominal trauma patients who were treated at the Emergency Department of Mohammad Hoesin Palembang Hospital who met the inclusion and exclusion criteria, as many as 114 people. The inclusion criteria were male or female patients aged $\geq 15$ years, penetrating abdominal stab wounds and blunt abdominal trauma with positive FAST. While exclusion criteria are critical patients who have endotracheal tubes attached and there is a history of other operations.

The mechanism of injury is assessed by history taking and physical examination to determine whether the type of trauma is blunt or translucent. To assess the RTS (Revised Trauma Score), it is done by assessing the GCS (Glasgow coma scale), systolic blood pressure (SBP) and respiratory frequency $(\mathrm{RF})$, then an assessment is carried out with the formula $\mathrm{RTS}=$ $(0.9368 x \mathrm{GCS})+(0.78326 x \mathrm{SBP})+(0.2908 \mathrm{xRF})$. Mortality assessment is done by assessing medical records related to patient status, in the form of death or outpatient care.

Data analysis was performed with IBM SPSS 24 which was presented descriptively in tables and diagrams and determined the correlation of the RTS assessment of the mortality rate of abdominal trauma sufferers using the Mann Whitney, Chi Square and Fisher Exact Test methods. 


\section{STS SRIWIJAYAJOURNAB OFEURGERY}

\section{Results}

Based on the results of this study, some characteristics of abdominal trauma sufferers are summarized in Table 1. The average age of people with abdominal trauma who died was $32 \pm$ 16,195 years, higher than the average living survivor, which was $28.65 \pm 10.878$ years. Also, in this study, all of patient who died were man However, there was no significant relationship among patient's age, sex and mortality, as indicated by the $\mathrm{p}$ value.

Most of the patients who died had blunt abdominal trauma, namely 6 people $(14.6 \%)$ of 41 patients who experienced blunt trauma. While patients died with penetrating trauma mechanism are 3 people $(4.1 \%)$ of 73 patients who suffered penetrating injuries. The $p$ value of the mechanism of trauma to death in abdominal trauma is 0.046 or there is a significant relationship. Based on the act of emergency laparotomy, there were 7 people (7.7\%) of those who died had had a previous laparotomy. Whereas 2 people $(8.7 \%)$ did not undergo laparotomy. The results of $\mathrm{p}$ Laparotomy emergency response to death in abdominal trauma patients is 0.873 or there was no significant relationship.

The $p$ value of the length of stay in relation to death in abdominal trauma patients is 0.001 or has a significant relationship. Patient died having a shorter mean of $3.67 \pm 2.449$ days than living patients which was $7.70 \pm 2.787$ days. Based on the duration of the trauma to the admission patient at the Emergency Department, the mean group of patients who died and patients who lived was not much different, namely $7.89 \pm 7.897$ hours and $9.73 \pm 13.13$ hours with a p value of 0.700 or not significantly related. Based on systolic blood pressure, the group of patients who had a lower mean systolic blood pressure was $98.89 \pm 27.31$ while in the group of living patients was $105.9 \pm 21.559$. The $\mathrm{p}$ value of the relationship between systolic pressure and death is 0.350 or does not have a significant relationship. Based on the respiratory frequency, the group of patients who died had a faster breathing frequency of $31.11 \pm 5.051$ compared to the group of living patients which was $26.92 \pm 4.819$. While the $\mathrm{p}$ value of the relationship between respiratory frequency of abdominal trauma sufferers with death is 0.024 or has a meaningful relationship. Based on the Glasgow Coma Score (GCS) level, it was found that the average group of abdominal trauma 


\section{STS SRIWIJAYAJOURNAB OFEURGERY}

patients who died was lower at $13.44 \pm 2.332$ compared with patients who lived at $14.74 \pm 1.109$. The $p$ value of the relationship between GCS and death in abdominal trauma patients is 0.010 or has a significant relationship. Based on the pulse frequency, the group of abdominal trauma patients who died had a faster pulse frequency which was $112.67 \pm 12.694$ compared to the group of survivors which was $101.42 \pm 13.336$. The $\mathrm{p}$ value of the relationship of pulse frequency with death in abdominal trauma patients is 0.024 or has a significant relationship. Based on the assessment of the Revised Trauma Score (RTS), the average RTS score of the group of abdominal trauma patients who died was lower at $6.628 \pm 0.795$ compared to the group of living patients at $7.459 \pm 0.795$. The $\mathrm{p}$ value of the relationship of RTS value to death in abdominal trauma patients is 0.003 or has a meaningful relationship. 


\section{STS SRIWIJAYA JOURNAB OFEURGERY}

Table 1. Research Variables

\begin{tabular}{|c|c|c|c|}
\hline \multirow[t]{2}{*}{ Variables } & \multicolumn{2}{|c|}{ Mortality } & \multirow[t]{2}{*}{$P$ Value } \\
\hline & $(+)$ & $(-)$ & \\
\hline Age & $32 \pm 16,195$ у.о. & $28,65 \pm 10,878$ у.о. & $0,705 \mathrm{a}$ \\
\hline \multicolumn{4}{|l|}{ Sex } \\
\hline Male & $9(7,9 \%)$ & $105(93,1 \%)$ & $0,607 b$ \\
\hline Female & 0 & $3(100 \%)$ & \\
\hline \multicolumn{4}{|l|}{ Injury Mechanism } \\
\hline Blunt & $6(14,6 \%)$ & $35(85,3 \%)$ & $0,046^{c}$ \\
\hline Penetrating & $3(4,1 \%)$ & $70(95,8 \%)$ & \\
\hline \multicolumn{4}{|l|}{ Laparotomy } \\
\hline Laparotomy (+) & $7(7,7 \%)$ & $84(92,3 \%)$ & $0,873^{\mathrm{c}}$ \\
\hline Laparotomy (-) & $2(8,7 \%)$ & $21(91,3 \%)$ & \\
\hline Length of Stay & $3,67 \pm 2,449$ hari & $7,70 \pm 2,787$ hari & $\mathbf{0 , 0 0 1}{ }^{\mathrm{a}}$ \\
\hline Trauma Duration & 7,89 $\pm 7,897$ jam & $9,73 \pm 13,13$ jam & $0,700^{\mathrm{a}}$ \\
\hline Pulse Frequency & $112,67 \pm 12,649$ & $101,42 \pm 13,363$ & $0,024^{a}$ \\
\hline Systolic Blood Pressure & $98,89 \pm 27,31$ & $105,9 \pm 21,559$ & $0,350^{\mathrm{a}}$ \\
\hline Respiratory rate & $31,11 \pm 5,051$ & $26,92 \pm 4,819$ & $\mathbf{0 , 0 2 4 ^ { \mathrm { a } }}$ \\
\hline Glasgow Coma Scale (GCS) & $13,44 \pm 2,332$ & $14,74 \pm 1,109$ & $0,010^{\mathrm{a}}$ \\
\hline Revised trauma score(RTS) & $6,628 \pm 0,795$ & $7,459 \pm 0,795$ & $\mathbf{0 , 0 0 3}{ }^{\mathrm{a}}$ \\
\hline
\end{tabular}

$\mathrm{a}=$ Mann Whitney test, $\mathrm{p}=0,05, \mathrm{~b}=$ fisher exact test, $\mathrm{p}=0,05, \mathrm{c}=$ chi square test $, \mathrm{p}=0,05$ 


\section{SIS SRIWIJAYA JOURNAB OFEURGERY}

\section{Discussion}

Abdominal trauma is broadly divided into blunt trauma and penetrating trauma. Penetrating trauma is the entry of a certain object through the cavity peritoneum. The most common cause is firearms, stab wounds and other substances that can penetrate the viscera organs. In this penetrating trauma the most frequently injured organs are the small intestine, colon and liver. In blunt trauma there is no substance that penetrates into the abdominal organs. Effects of trauma to the abdominal wall which transmits to the viscera and cause injury to the viscera organs by direct mechanism or deceleration. The most injured organs in blunt abdominal trauma are the spleen and liver. In this study, the number of penetrating trauma patients was greater than the number of blunt trauma sufferers. The blunt trauma was 41 people (36\%). The cause of blunt trauma in this study sample was due to traffic accidents as many as 35 people (30.7\%), falling from a height of 6 people $(5.2 \%)$. Overall penetrating trauma there were 73 patients. The cause of penetrating trauma in this study was 66 puncture wounds (57.9) and 7 gunshot wounds (6.1\%). Other studies state that the most mechanism of abdominal trauma is penetrating trauma, which is $78.76 \%$. This is consistent with the results of this study. However, the most common cause of penetrating wounds in Bordoni et al's study was gunshot wounds (89.28). Different results were obtained by Costa et al in Italy in 2010. Costa et al reported in their study that abdominal trauma was caused mostly by blunt trauma (97\%). Most were caused by traffic accidents (75.9\%), falls from heights (6.3), accidents at work $(5.06 \%)^{4}$

Of 114 abdominal trauma sufferers, there were 9 people who died (7.9\%). This result is higher than the study conducted by Song et al, where the successive mortality rates from 2011 to 2014 were 5.89\%, 5.75\%, 5.79\%, and 5.62\%. Different results were reported by Costa et al., which obtained a mortality rate of $24.1 \%$. Bleeding is the most common cause of death that can be prevented in trauma patients. Injury to the abdominal organs is an important source of bleeding. But it is difficult to diagnose abdominal organ injury so the therapeutic approach becomes difficult especially when accompanied by other organ injuries. ${ }^{12-14}$ This is because almost half of the bleeding in the peritoneal cavity or in the retroperitoneum gives symptoms that are mild or even asymptomatic. Besides that, the accuracy of abdominal physical examination is low and the level of consciousness is difficult to determine due to abdominal organ bleeding or due to central 
nervous injury. For this reason, although no abdominal pain or signs of peritonitis are found on physical examination, it cannot be ruled out the possibility of abdominal injury.

In this study, the majority of abdominal trauma patients, namely 91 people (79.8) performed emergency laparotomy. The indication of the most emergent laparotomy in this study was peritonitis with 39 people (34.2\%). Other indications of surgery are hemodynamically unstable in 20 patients $(17.5 \%)$ and intestinal evisceration in 11 people $(9.6 \%)$. These results are different from the study conducted by Gad et al in Egypt in 2012. Gad et al reported that 28.3\% of abdominal trauma patients were performed laparotomy. In the research conducted by Costa et al reported that abdominal trauma sufferers who underwent laparotomy were $51.9 \%$. ${ }^{15-19}$

In this study, the mean length of stay for abdominal trauma sufferers was 7.39 days. With the shortest length of stay is 1 day and the longest length of stay is 15 days. With a median of 7 days. This is in accordance with research conducted by Saleem et al in Egypt in 2016. Saleem et al in his study stated that the average length of stay for abdominal trauma patients was 6,75 days with a median of 7 days. ${ }^{20}$

Based on the duration of the incident of trauma until the admission patient in the Emergency Installation of Mohammad Hoesin General Hospital in this study obtained an average of 9.54 hours. The shortest time is 1 hour and the longest time is 96 hours and the median is 6 hours. The duration between the incidence of trauma to the patient admitted to the emergency room is an important factor. ${ }^{21}$ For example $80 \%$ of people with blunt abdominal trauma who experience treatment delay for 60-90 minutes die while in the emergency room, where the majority of blunt abdominal trauma managed less than 60 minutes can last (76.3). Likewise, $81.8 \%$ of patients with fatal abdominal penetrating trauma experience a delay of management for 60-90 minutes, where $75 \%$ of patients with penetrating abdominal trauma who are treated for less than 60 minutes can survive.

In the examination of systolic blood pressure of patients at admission in this study, the mean value of $105 \mathrm{mmHg}$ was obtained. The lowest systolic blood pressure is $40 \mathrm{mmHg}$ and the highest systolic blood pressure is $150 \mathrm{mmHg}$, the median is $110 \mathrm{mmHg}$. To see the distribution we divided the 2 groups, namely the group with systolic blood pressure $<90 \mathrm{mmHg}$ there were 26 people (22.8\%) and the group with systolic blood pressure $\geq 90 \mathrm{mmHg}$ that was 88 people (77.2\%). We also performed a bivariate test to see the relationship between systolic blood pressure and 


\section{STS SRIWIJAYAJOURNAB OFEURGERY}

death in abdominal trauma patients. The result is no significant relationship between systolic blood pressure and death in abdominal trauma patients. In cases of trauma, hypotension is a late symptom and a sign of class III hypovolemic shock, where there has been loss of 30-40\% of the total blood volume and this is associated with high mortality rates. Patients with milder blood loss initially have "normal" systolic blood pressure, but later develop into irreversible shock if no appropriate intervention is performed. ${ }^{22}$

In this study, the respiratory frequency at admission was found to be $27 \pm 5,085$ times per minute with the lowest frequency being 20 times per minute and the highest frequency was 40 times per minute. Most of patients came with respiratory frequency of 11-29 times per minute with 69 patients (60.5), while the rest had respiratory frequency 30 times per minute $(39.45 \%)$. It also performed a bivariate analysis of respiratory frequency for death in abdominal trauma patients. The mean respiratory frequency in the group of patients who died was $31 \pm 5,051$, while the mean respiratory frequency in the group of patients who did not die was $26 \pm 4,819$. From the bivariate analysis test it was found that respiratory frequency significantly affected death in abdominal trauma patients with $\mathrm{p}$ value of 0.024 .

In patients with arterial pressure $>60 \mathrm{mmHg}$, activating peripheral chemoreceptors in the carotid arteries (due to decreased perfusion) causes chemoreceptor reflexes. This causes peripheral nervous system activity and increases respiratory stimulation resulting in an increase in respiratory frequency and increased ventilation. At very low arterial pressure, below $40 \mathrm{mmHg}$, inadequate blood vascularization in the brain causes the activation of a very strong sympathetic nervous system and vasoconstriction in response to brain ischemia. ${ }^{23}$

In this study we assessed the GCS values of abdominal trauma patients. The mean GCS value in this study was $14.591 \pm 1.480$. Where the lowest GCS value is 3 and the highest GCS value is 15 . For the equivalent, the most in the GCS value group is $13-15$, namely 110 patients (96.5\%). We performed a bivariate test of the effect of GCS on mortality in patients with abdominal trauma. The mean value of GCS in the group of patients who died was $13.44 \pm 2.332$ and the mean in the group of patients who did not die was $14.74 \pm 1.109$. From the bivariate test in this study found a significant relationship between the value of GCS with death in abdominal trauma patients with a $\mathrm{p}$ value of 0.010 . 


\section{SSS SRIWIJAYAJOURNABOPSURGERY}

In the calculation of the RTS formula, the value of GCS has the highest coefficient value. For this reason sufferers with head injuries who have decreased consciousness have a low RTS value and are potentially classified as more severe injuries. Whereas in patients with abdominal and thoracic trauma who at the time of initial admission have not shown a decrease in awareness of the RTS value will be higher.

We assessed the Revised Trauma Score for all samples in this study. The mean RTS value obtained is 7,393 with the smallest RTS value is 1,605 and the highest RTS value is 7,841 , and the median is 7,841. We calculated the mean RTS values in the group of dead patients and living patients. The mean RTS of abdominal trauma patients who died was 6.628 while the mean RTS in the group of living patients was 7.459. We also performed a statistical test to see whether there was a relationship between the value of RTS and mortality in abdominal trauma patients. The result is that there is a significant relationship between RTS values with death in abdominal trauma patients.

\section{Conclusion}

There is a significant relationship between the Revised Trauma Score (RTS) trauma assessment system to death in abdominal trauma patients.

\section{Conclusion}

Terdapat hubungan yang bermakna antara sistem penilaian trauma Revised Trauma Score (RTS) terhadap kematian pada pasien trauma abdomen.

\section{References}

1. Norouzi V et al. Calculation of the Probability of Survival for Trauma Patients Based on Trauma Score and the Injury Severity Score Model in Fatemi Hospital in Ardabil. Archives of Trauma Research. 2013. 30-4 


\section{SSS SRIWIJAYA JOURNABOPSURGERY}

2. Akbari G, Mohammadian A. Comparison of the RTS and ISS Scores on Prediction of Survival Chances in Multiple Trauma Patients. Acta Chirurgiae Orthopaedicae et Traumatologiae Cechosil. 2012p 535-9

3. Ranti j, Sapan H, kelesarab L. Aplikasi Revised Trauma Score (RTS), Injury Severity Score (ISS) dan Trauma Related Injury Severity Score dalam memprediksi mortalitas pada pasien multitrauma di IRDB BLU RSUP Pof. Dr. R.D. Kandou Manado.2015

4. Costa et al. The Epidemiology and Clinical Evaluation of Abdominal Trauma. An analysis of a multidisciplinary Trauma Registry. Annual Italian Chirrurgica. Roma, Italy. 2010, 81 : 95-102

5. Salim C. Sistem Penilaian Trauma. Departemen Ilmu Bedah Dr. Drajat Prawiranegara, Serang, Banten, Indonesia. CDK-232/vol. 42 n0.9, Th 2015

6. Kondo et al. Revised Trauma Scoring System to Predict in-hospital mortality in the emergency departement: Glasgow Coma Scale, Age and Systolic Blood Pressure Score. Jepang. Critical Care 2011, 15: R191

7. Domingues $\mathrm{C}$ et al. Performance of Trauma and Injury Severity Score (TRISS) adjustments; an : integrative review. Rev Esc Enferm. 2015; 49; 135-43

8. Domingues $\mathrm{C}$ et al. The Role of the New Trauma and Injury Severity Score (NTRISS) for Survival Prediction. Rev Esc Enferm USP. 2011; 45; 1353-8

9. Ebrahimi M. Pirazgandhi H, Reihani H. How is injury Severity Scored? A brief review of scoring system. Departement of Emergency Medicine, University of Medical Science, Mashhdad Iran. Rev Clin Med 2015; vol 2(No.3); 125-8

10. Khayat et al. Correlation of Revised Trauma Score with Rate of Traumatic Patient within the First 24 hours of Hospitalization. Iran. Res Med Sci 2014; 16 (11): 33-36

11. Alvarez et al. Analysis of the Revised Trauma Score (RTS) in 200 Victims of Different Trauma Mechanism. Brazilia. Rev. Columbia. Bras. Cirhurgica. 2016; 43(5):334-340

12. Roy V et al. Validation of Internasional Trauma Scoring System in Urban Trauma Centres in India. India. Injury. Int J. Care Injured 47 (2016) 2459-2464

13. Kim SC et al. The Revised Trauma Score plus Serum Albumin Level Improves the Prediction of Mortality in Trauma Patients. Republik Korea Selatan. American Journal of Emergency Medicine 35 (2017) 1882-1886 


\section{SSS SRIWIJAYAJOURNABOPSURGERY}

14. Miller RT et al. The Modified rapid Emergenccy Medicine Score: A Novel Trauma Triage yool to Predict in-hospital Mortality. Las Vegas, Amerika Serikat. Injury vol 48 Issue 9. 2017. P 1870-1877

15. Guideline for essential trauma care. The International Ascociation for the Surgery of Trauma and Surgical Intensive Care. Worlf Health Organization. 2004

16. Tana L. factor yang berperan pada lama rawat inap akibat cedera pada kelompok pekerja usia produktif di Indonesia. Puslitbang Sumber Daya dan Pelayanan kesehatan. Badan Litbang Kesehatan Kemenkes RI. Buletin Penelitian Sistem Kesehatan vol 19. No. 1 Januari 2016, hal $75-82$

17. Hariharan S et al. Evaluation of Trauma Care Applying TRISS Methodology in a Caribbean Developing Country. International Emergency Medicine. Vol 37, No. 1 pp. pp. 85-90. 2009

18. Cedera. Riset Kesehatan Dasar (RIKESDAS 2013). Badan Penelitian dan Pengembangan Kesehatan Kementrian Kesehatan RI. 2013

19. Di Maggio C et al. Traumatic Injury in the United States: In-Patient Epidemiology 2000-2011. Department of Surgery Division Trauma and Acute Care Surgery. New York. Injury. 2016 July; 47(7); 1393-1403

20. Gupta RT. Abdominal Trauma. Textbook of Gastrointestinal Radiology. Forth Edition. Elsevier Saunders. 2015.p2282-2294

21. James R. Nichols III I. Michael A. Puskarich. Abdominal Trauma. Rosen's Emergency Medicine. Concept and Clinical Practice. Volume 1. Elsevier Saunders. 2018.p 404-417

22. Brenner M. Hicks C. Major Abdominal Trauma. Critical Decision and New Frontiers in Management. Damage Control: Advances in Trauma Rescucitation. Emergency Medicine Clinics of North America. Volume 36 number 1. February 2018. p149-159

23. Walter L. Biffl. Ari Leppaniami. Management Guidelines for Penetrating Abdominal Trauma. Surgical Symposium Contribution. Amerika Serikat. World Journal of Surgery. 2014. 